\title{
Essay
}

\section{The American Science Pipeline: Sustaining Innovation in a Time of Economic Crisis}

\section{Gillian Hue, ${ }^{*}$ Jessica Sales, ${ }^{+}$Dawn Comeau, ${ }^{+}$David G. Lynn, ${ }^{\ddagger}$ and Arri Eisen ${ }^{\S}$}

\author{
${ }^{*}$ Center for Ethics, ${ }^{\dagger}$ Rollins School of Public Health, ${ }^{\ddagger}$ Department of Chemistry, ${ }^{\S}$ Department of Biology and \\ Institute of the Liberal Arts, Emory University, Atlanta, GA 30322
}

Submitted December 5, 2009; Revised July 30, 2010; Accepted July 30, 2010

Monitoring Editor: Vivian Siegel

\begin{abstract}
Significant limitations have emerged in America's science training pipeline, including inaccessibility, inflexibility, financial limitations, and lack of diversity. We present three effective programs that collectively address these challenges. The programs are grounded in rigorous science and integrate through diverse disciplines across undergraduate, graduate, and postdoctoral students, and resonate with the broader community. We discuss these models in the context of current economic constraints on higher education and the urgent need for our institutions to recruit and retain diverse student populations and sustain the successful American record in scientific education and innovation.
\end{abstract}

\section{INTRODUCTION}

While U.S. success in the twentieth century was built on the nation's scientific achievements, many of America's best and brightest students are choosing careers outside of science and are dropping out all along the educational pipeline. Profound implications from these changes are already apparent: the United States is falling behind India and China in scientific innovation (Branscomb, 2008; DeHaan and Narayan, 2008), qualified science educators in the United States at the K-12 level are in short supply (King, 2006), and many research and technological jobs are being sent overseas (Lieberman, 2004). The proportion of American students earning undergraduate degrees in science ranks only twentieth in the world; in 1989 the European Union passed the United States in number of science and engineering PhDs awarded; the majority of science postdoctoral fellows doing research in America today are from other nations; and while science publications increased $40 \%$ worldwide from 1992 to 2006, those written by Americans

DOI: $10.1187 /$ cbe.09-12-0091

Address correspondence to: Arri Eisen (aeisen@emory.edu).

(C) 2010 G. Hue et al. CBE_Life Sciences Education (c) 2010 The American Society for Cell Biology. This article is distributed by The American Society for Cell Biology under license from the author(s). It is available to the public under an Attribution-Noncommercial-Share Alike 3.0 Unported Creative Commons License (http://creativecommons.org/licenses/bync-sa/3.0). decreased 10\% (Olefsky, 2007). Rising above this gathering storm (National Academy of Science, National Academy of Engineering, and Institute of Medicine, 2007) has now been seriously impacted by the 2008 global economic downturn, constraining our options for science education reform.

A knee-jerk reaction to the economic crisis is to first eliminate innovative and interdisciplinary programs; a more thoughtful approach would include maintaining and even strengthening programs that are proven to work in the new interdisciplinary, networked environment of the twentyfirst century, rather than falling back on traditional models that may be partially responsible for our problems in the first place.

Higher education clearly bears some responsibility for pipeline disrepair, and accordingly our institutions must take the lead in improving academic opportunities. Specifically, scientists and science educators must more effectively recruit and retain a diverse science student populationfrom entry into college, to graduate school, to postdoctoral fellowships, and to careers in science. How can the educational community effect such change? We outline three experiments, On Recent Discoveries by Emory Researchers (ORDER), Fellowships in Research and Science Teaching (FIRST), and Interdisciplinary Fellowships in Science and Society (IFSS), as an integrated approach for pipeline repair. When coordinated, these efforts bring into focus common interrelated adjustments to the traditional higher education academic model through the following: 1) a multidisciplinary focus in introductory and capstone science courses, 
the critical "checkpoints" in college; 2) vertical integration and mentoring across the pipeline; and 3) greater flexibility, diversity, and accessibility for pipeline entry.

\section{ORDER}

People generally learn best when they experience ideas and information in a rich, societal context related to their lives (Bransford, 2000). The traditional structure of introductory science courses does not always afford opportunities to address contemporary cross-disciplinary issues, nor does it capture the process of scientific discovery (Powell, 2003). ORDER, initiated in 2003 with funding from the Howard Hughes Medical Institute, complements traditional introductory science courses and addresses these learning challenges by vertically integrating resources up and down the pipeline. Through a competitive process, graduate students and postdoctoral fellows from across the humanities, social sciences, and natural sciences are selected as Teacher-Scholars for the program. The Teacher-Scholars form interdisciplinary teams that design and teach both freshman seminar and senior capstone courses. The courses are based directly on the ongoing research discoveries of the Teacher-Scholars doing the teaching. ORDER Teacher-Scholars, provided with pedagogical tools and mentoring from their professors, collectively design learning activities to meet their course objectives. Throughout the fellowship, the Teacher-Scholars are also provided with mentoring in the elements of scientific teaching, assessment and evaluation, and professional development.

Each Teacher-Scholar cohort unites its work under a common theme. Because the courses are based directly on the current research of each Teacher-Scholar, no two ORDER seminars are exactly alike. One seminar in 2007/2008, for example, "Translating Life, Bridging the Languages of Science and the Human Spirit," was taught by scientists training in primatology, anthropology/linguistics of religion, psychology, biophysics, and stem cell biology. Other graduate students and fellows studying cancer, synthetic biology, ecology of parasitism, anthropology/early art, and the chemistry of life's origins taught another seminar entitled "A Method to the Madness." Undergraduate students in such courses learn about the research discoveries of the Teacher-Scholars in real time as their discoveries are being made. Students visit Teacher-Scholars' laboratories, see the process of science in action in a rich interdisciplinary context, and use their near-peer mentors as guides to design and implement their own original research proposals. The student research proposals have not only served as capstone writing experiences for the graduating senior but have also been used successfully as the basis of graduate predoctoral research proposals.

From the Teacher-Scholar perspective, survey results demonstrate that ORDER provides an important initial step toward better preparation for future academic careers (Sales et al., 2007). Specifically, because of their teaching in the ORDER program, these young scholars indicate they feel more integrated into the larger university community, more knowledgeable of what an academic position entails, and inspired and empowered to pursue their individual academic scholarship. Without such social capital, the drop-out rate increases, especially among minorities and women, along the science pipeline (Stewart et al., 2004; Wagner, 1992). In fact, since 2003, there have been 60 graduate/ postdoctoral students who have served as ORDER TeacherScholars (26 male, 34 female), and, in contrast to the only $68 \%$ of national earned doctoral students who have definite postgraduate plans (National Science Foundation, 2006), all Teacher-Scholars (48) who have completed their graduate training have continued along the pipeline to assume postdoctoral positions (13) or academic appointments (35) in mathematics, engineering, physics, chemistry, biology, psychology, anthropology, neuroscience, public health, or sociology. Although we have yet to establish direct cause and effect, the correlation between experience as a TeacherScholar and continued success in the pipeline is striking. Strong support for the impact of their ORDER experience is that Teacher-Scholars continue to critically examine and publish on their experiences in ORDER (Wilhelm et al., 2009; Campbell, 2010).

The positive correlation between undergraduate participation in ORDER and their participation in research is also striking. Nearly 800 undergraduate students have successfully completed ORDER courses, and more than $80 \%$ of these students have pursued further research training as research assistants or on honors thesis projects across various departments at Emory and in other academic institutions. By comparison, fewer than half that number of Emory graduating seniors in 2008 worked on a research project with a faculty mentor (Success after Emory, Class of 2008 Statistics, 2008). Assessment also finds that ORDER undergraduate students demonstrate improved science-related skills and critical thinking ability (Sales et al., 2006). The undergraduates in these courses attribute ORDER's success to the interdisciplinary nature of the courses and to the graduate students and postdoctoral fellows who teach and mentor them-near-peer models who intensively immerse the undergraduates in a rigorous preview of the next steps in the academic pipeline. Taken together these data strongly suggest this experiment in scientific teaching strengthens the pipeline at yet another juncture, by helping increase the numbers of undergraduate students actively participating in science and scientific research.

\section{FIRST}

FIRST is a National Institutes of Health (NIH)-supported three-year postdoctoral fellowship that adds 10 new fellows each year. This program expands the options for science careers by enriching portfolios of FIRST fellows to include intensive and extensive experience in teaching and related career development opportunities at historically minority institutions, including Spelman College, Morehouse College, Clark Atlanta University, and the Morehouse School of Medicine (Institutional Research and Academic Career Development Awards). While completing a three-year NIH postdoctoral fellowship, fellows take a semester-long How to Teach course and then develop and teach, with a professor mentor, an undergraduate course at one of the minority serving schools.

Like ORDER, FIRST has borne out research suggesting a strong supportive environment is a crucial factor in devel- 
oping successful scientists (Wagner, 1992; Stewart et al., 2004). The 114 fellows who have completed or are currently in the program have published more than 200 peer-reviewed articles with their FIRST research mentors. In addition, fellows have published 336 articles with authors other than their FIRST mentors, and the mean publication rate for FIRST fellows equals that of a nonteaching control group at the same institution over the same period $(0.81 \pm 1.1 \mathrm{com}-$ pared with $0.76 \pm 1.2)$. The additional teaching instruction and obligations have no negative impact on publication rate. Consistent with the goal and societal need of providing well-prepared scientists for a broad range of scientific careers, FIRST fellows have careers as tenure-track professors in liberal arts colleges (including 10 at historically minority institutions), research universities, community colleges, science education and development in high schools, the pharmaceutical industry, and medical research centers. The fellows are from diverse scientific fields and include a considerable representation of minorities (53\%) and a majority of women (73\%). The demonstrated success of FIRST fellows as career scientists is an important measure of strengthening the pipeline at several critical points. By improving the quality of training for academic positions, FIRST engages women and minorities in science at the undergraduate level through the students at the minority-serving institutions that are included in this program, as well as at the postdoctoral level (the fellows). In fact, the number of minority postdocs at Emory has dramatically increased since the inception of the FIRST program; FIRST fellows have constituted on average $33 \%$ of the minority fellow population at the entire institution over the last nine years.

This vertically and horizontally integrated experience broadens and strengthens access to the pipeline at many levels. Individuals who were undergraduates at the historically minority schools have returned as FIRST fellows, taught current undergraduates at their former institutions, and have been hired as faculty at those same schools in biology, psychology, and chemistry. The FIRST program has worked closely with, and was instrumental in establishing, Emory's Office of Postdoctoral Education (OPE), which serves all fellows within the institution). FIRST and OPE now share ideas, evaluation strategies and other resources, and cosponsor speakers and career development workshops. One FIRST fellow used her interests and experience with FIRST to participate in and evaluate the ORDER program (Sales et al., 2006, 2007). Several graduate students who were ORDER Teacher-Scholars have also used their experience to competitive advantage in applying for FIRST postdoctoral fellowships. FIRST then creates new connections to institutional resources and enables the fellows to pursue a wide variety of careers, both inside and outside the traditional pipeline (Brommer and Eisen, 2006).

\section{IFSS}

Building on this foundation, Emory initiated a third experiment to strengthen its pipeline in 2007. Funding for IFSS was provided by Emory's Strategic Plan, to focus broadly on integrating science, education, and ethics. The IFSS fellows are both model and medium for strengthening the pipeline. They have taught courses that are cross-listed in multiple departments, providing a formal connection across traditional units. One fellow, for example, teaches a course listed simultaneously in the Religion and Environmental Sciences Departments and has offices in Biology and the Center for Ethics. These fellows have also moved beyond the academy to create direct engagement with the larger community. Through high school science teacher interaction and education on issues of science and ethics, to directly working with church communities, the fellows create formal and informal science education relevant for the entire community. Nationally, other programs have captured this concept by seeding university science departments with faculty who also have training specifically in education, and in at least one state university system (California) the number of scientists hired with such specializations has more than tripled since 2000 (Bush et al., 2008). The uniqueness of IFSS lies in the empowerment of the interdisciplinary fellow in a role that bridges traditional units.

Merging seemingly disparate disciplines enriches pipeline flexibility, and the outreach efforts provide societal relevance to a diverse community. The robustness of this emerging network is apparent in the institution's response to new educational opportunities. For example, in recognition of the bicentennial of the birth of Charles Darwin and the $150^{\text {th }}$ year of the publication of On the Origin of Species, the College of Arts and Sciences at Emory joined forces to create the Evolution Revolution Symposium as a public discussion on our scientific future (Evolution Revolution Symposium, 2008). We invited scientists to discuss their work to understand the primate brain, the evolution of disease and development, and the chemical origins of life on Earth. We combined them with 60 local high school science teachers following a workshop on teaching evolution, professional artists from across the country, and hundreds of participants in a day-long town hall meeting. In February of 2009, the artists returned to campus to present the first of their responses to the Symposium concepts in plays, music, exhibitions, and dance. The ability to reach the public about scientific issues and technological achievement remains critical, particularly regarding this central tenet of biology that is so controversial to large segments of the population. Artistic contributions provided an exciting new medium for this larger dialogue (Evolution Revolution Symposium, 2008), a dialogue that would not have been possible without the infrastructure of the Emory network.

While academic departments provide disciplinary expertise and rigor and are the foundational pillars of our institutions, the experiments discussed here suggest the American university today can benefit from dynamic intellectual networks able to capture a richer and more diverse community. Interconnecting traditional disciplines can repair the pipelines that have been less accessible to women and minorities, support diverse pathways through the academy, and empower developing scholars to forge a path specific to their talents. Such networks remain fragile within our traditional pipeline, and indeed the economic downturn has significantly reduced funding for graduate education and innovative programs like we describe here at our and other institutions. A financial realignment can open space for new growth, and these new networks that have emerged from experimentation, assessment, and dissemination must remain a priority. In this time of unlimited access to informa- 
tion, such networks are essential to repairing our science education pipeline in the marketplace of science and technology.

\section{REFERENCES}

Branscomb, L. M. (2008). Science and industry: research alone is not enough. Science 321, 915-916.

Bransford, J. (2000). How People Learn: Brain, Mind, Experience, and School (Expanded ed.). Washington, DC: National Academy Press.

Brommer, C. L., and Eisen, A. (2006). FIRST: a model for increasing quality minority participation in the sciences from the undergraduate to the professoriate level. Journal of Women and Minorities in Science and Engineering 12, 35-46.

Bush, S. D., Pelaez, N. J., Rudd, J. A., Stevens, M. T., Tanner, K. D., and Williams, K. S. (2008). The pipeline: science faculty with education specialties. Science 322, 1795-1796.

Campbell, M. (2010). ORDERed Chaos: Connecting Students with Research at Emory University. Paper presented at the Institutional Research and Academic Career Development Awards.

Evolution Revolution Symposium (2008). www.emory.edu/evolution (accessed 24 August 2010).

DeHaan, R. L., and Narayan, H. M. V. (2008). Education for innovation: a tri-national overview. In: Education for Innovation: Implications for India, China, and America, ed. R. L. DeHaan and H. M. V. Narayan, Rotterdam: Sense Publisher, 3-16.

Institutional Research and Academic Career Development Awards (IRACDA) www.nigms.nih.gov/Training/CareerDev/MOREInstRes. htm (accessed 20 May 2010).

King, L. (2006). Lack of math, science teachers prompts U.S. alarm. USA Today, January 29, 2006. www.usatoday.com/tech/science/ 2006-01-29-teacher-shortage_x.htm (accessed 24 August 2010).

Lieberman, J. I. (2004). Offshore outsourcing and America's competitive edge: losing out in the high technology RandD and services sector [White Paper]. http://lieberman.senate.gov/assets/pdf/off_ shoring.pdf.

National Academy of Science, National Academy of Engineering, and Institute of Medicine (2007). Rising Above The Gathering Storm: Energizing and Employing America for a Brighter Economic Future, Washington, DC: National Academies Press.

National Science Foundation (2006). US Doctorates in the 20th Century, SRS Special Reports. www.nsf.gov/statistics/nsf06319 (accessed 24 August 2010).

Olefsky, J. M. (2007). The US's changing competitiveness in the biomedical sciences. J. Clin. Invest. 117, 270-276.

Powell, K. (2003). Science education: spare me the lecture. Nature $425,234-236$.

Sales, J., Comeau, D., Liddle, K., Khanna, N., Perrone, L., Palmer, K., and Lynn, D. (2006). Bridging the gap: a research-based approach for teaching interdisciplinary science to undergraduate freshman students. J. Coll. Sci. Teach. 35, 36-41.

Sales, J., Comeau, D., Liddle, K., Perrone, L., Palmer, K., and Lynn, D. (2007). Preparing future faculty. J. Coll. Sci. Teach. 36, 24-30.

Stewart, A. J., Vaque-Manty, D. L., and Malley, J. E. (2004). Recruiting female faculty members in science and engineering: preliminary evaluation of one intervention model. Journal of Women and Minorities in Science and Engineering 10, 361-375.

Success after Emory, Class of 2008 Statistics. (2008). Emory College of Arts and Sciences Senior Survey. www.college.emory.edu/about/ profiles (accessed 20 May 2010).

Wagner, U. (1992). Environments of Support. Washington, DC: American Council on Education, Publications Department ES.

Wilhelm, J., Fugate, J., Manzo, C., Rosa-Rodriguez, M., Simpson, D., and Hue, G. (2009). On recent discoveries by Emory researchers (ORDER): a research-based interdisciplinary seminar course. Paper presented at the Institutional Research and Academic Career Development Awards. www.nigms.nih.gov/Training/CareerDev/MOREInstRes.htm (accessed 20 May 2010). 